\title{
ANALYSIS OF A REINFORCED SOIL RETAINING WALL IN A PLATFORM EMBANKMENT
}

\section{Stefan Micevski}

Faculty of Civil Engineering, blvd. Partizanski odredi No.24, 1000 Skopje, Republic of Macedonia, Student

\section{Antonio Shoklarovski}

Faculty of Civil Engineering, blvd. Partizanski odredi No.24, 1000 Skopje, Republic of Macedonia, Student

\section{Bojan Susinov}

Faculty of Civil Engineering, blvd. Partizanski odredi No.24, 1000 Skopje, Republic of Macedonia, Student

Corresponding author: susinov@gf.ukim.edu.mk

\section{Sead Abazi}

Faculty of Civil Engineering, blvd. Partizanski odredi No.24, 1000 Skopje, Republic of Macedonia, Student

\begin{abstract}
In this paper, we numerically analyze a 9.0-m-tall reinforced soil retaining wall in a platform embankment, simulating the behaviour of its various components by using software and material models. The two basic constituents of the structure are the fill material and reinforcement. The designed reinforced soil retaining wall was built using local materials (sand with fine particles) on a base of sandy gravel. The design was analyzed with various software packages such as TensarSoil, Slide, and Plaxis 2D. The results show that the wall meets the requirements for both static and seismic conditions.
\end{abstract}

Keywords: Fill material, geogrid, numerical analysis, reinforced soil retaining wall

\section{ANALIZA POTPORNOG ZIDA OD ARMIRANOG TLA ZA NASIP PLATOA}

Sažetak: U ovome radu numerički smo analizirali zid od armiranog tla visine $9 \mathrm{~m}$ za nasip platoa, simulirajući ponašanje njegovih različitih komponenti, koristeći računalne programe i modele materijala. Dva osnovna elementa konstrukcije su materijal ispune i armatura. Projektirani zid od armiranog tla izgrađen je koristeći lokalne materijale (pijesak sa sitnim česticama) na podlozi od pjeskovitog šljunka. Problem je analiziran koristeći različite računalne programske pakete kao što su TensarSoil, Slide i Plaxis 2D. Rezultati su pokazali da zid zadovoljava projektne zahtjeve i za statičke i za seizmičke uvjete.

Ključne riječi: materijal ispune, geomreža, numerička analiza, potporni zid od armiranog tla 


\section{INTRODUCTION}

In the industrial zone near the city of Veles, a new factory is being constructed. Before this building was designed, detailed geotechnical reports on the area were prepared. In the first construction phase, a steel hall will be built in zone 1 (Figure 1), where the ground will be excavated extensively because of the terrain and the needs of the foundation. This excavated material will be used as embankment material in zone 2, as necessitated by the terrain [1].

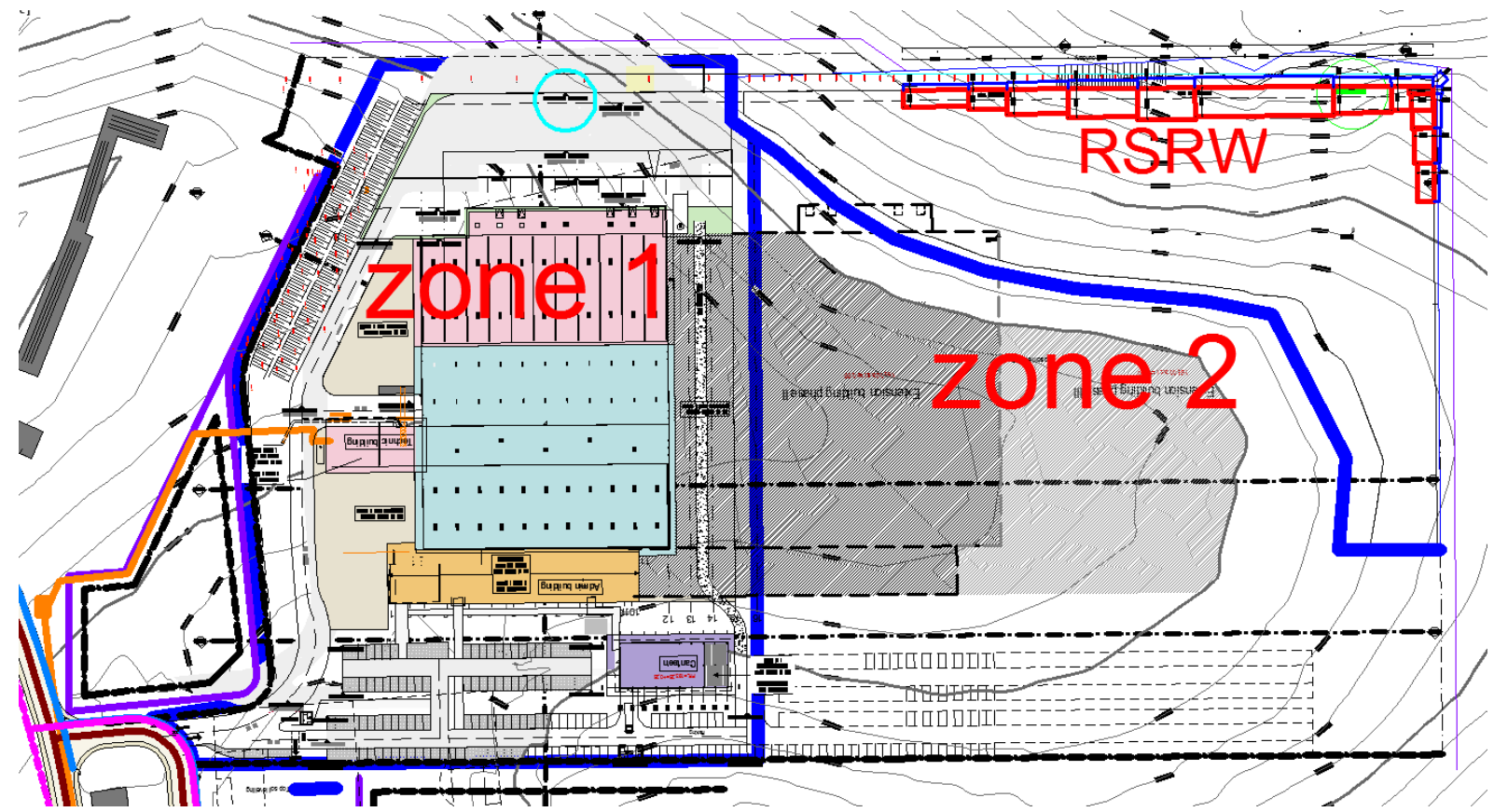

Figure 1 Plan view of the reinforced soil retaining wall

The embankment reaches a height of $9.0 \mathrm{~m}$, and it is necessary to build a retaining wall to stabilize the slope, near the boundary line. A proposed solution to stabilize the slope was to build a reinforced soil retaining wall (RSRW). This system is different from traditional retaining structures, as it uses both fill material and reinforcement as constructive elements. RSRWs have various advantages over traditional concrete retaining walls: they are more flexible; can tolerate large deformation without distress, even with seismic loads; do not require a foundation; can use onsite backfill material, saving time and transportation costs; and impose no limit to wall height [2].

In this paper we present numerical calculations of the stability and deformation of this reinforced soil structure, and we describe some interesting aspects of the construction.

\section{MATERIALS USED FOR CONSTRUCTION AND ANALYSIS}

The geotechnical reports show that the embankment material is classified as silty sand with gravely particles. However, the ground in zone 2 varies: the surface layer of some parts is clayey silt (ML/CL), as shown in Figure 2 , another is silty sand, while most parts are very compacted gravel (GW). There appears to be no groundwater.

The designed RSRW was built using local materials, namely silty sand, to avoid the need for long-distance transportation. Standard penetration tests in the field and laboratory tests show that this material has a natural unit weight of $\sim 19.0-20.0 \mathrm{kN} / \mathrm{m}^{3}$, a low cohesion of $\mathrm{c}=0.0-5.0 \mathrm{kPa}$, and a friction angle of $\varphi=23-25^{\circ}$. 


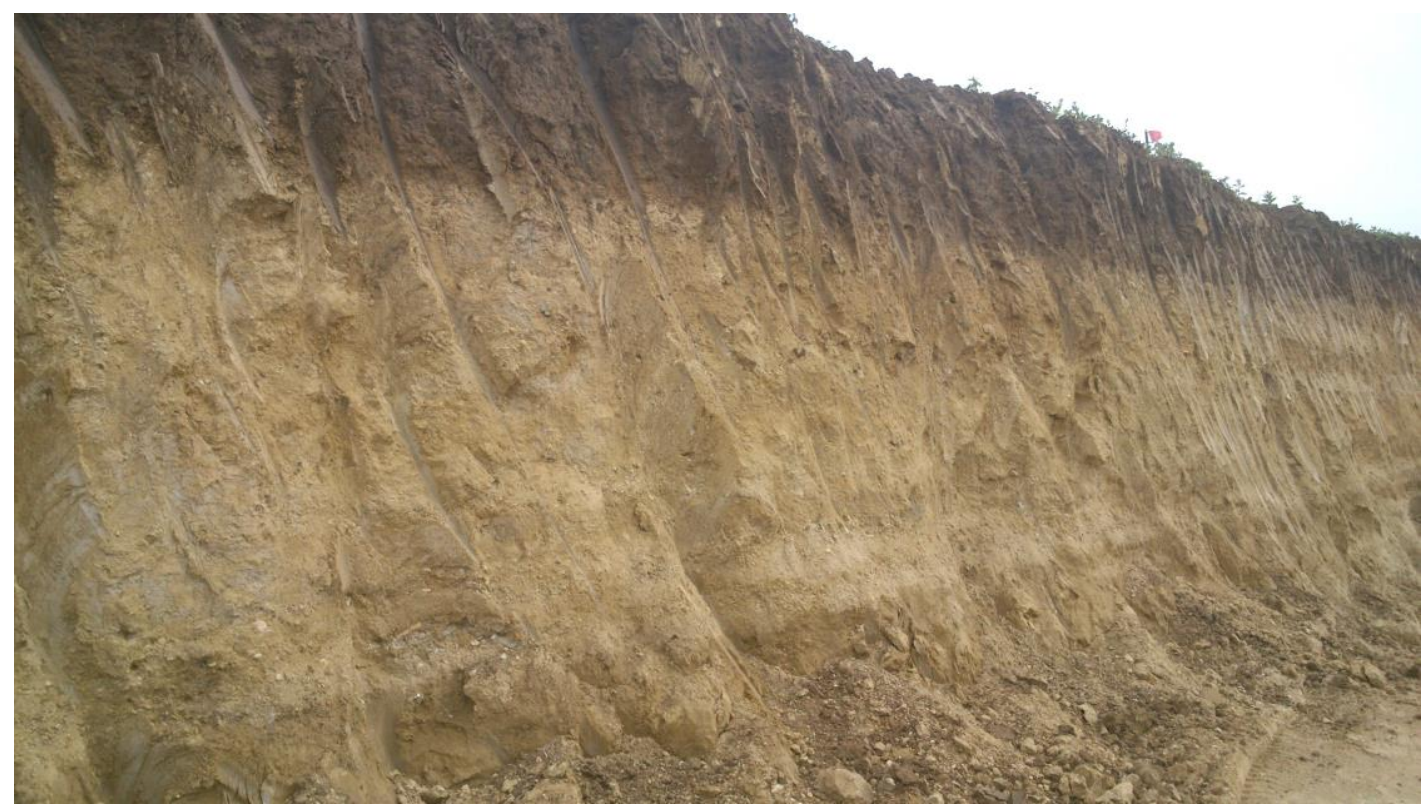

Figure 2 Ground profile after excavation in zone 1

The reinforcement was constructed with several types of materials, but mostly with geogrids (Figure 3). Calculations of the retaining wall suggested the use of uniaxial extruded geogrids made of high-density polyethylene with enhanced long-term tensile strength, whose mean short-term tensile strengths (tested in accordance with EN ISO 10319:2008) are $68 \mathrm{kN} / \mathrm{m}, 93 \mathrm{kN} / \mathrm{m}, 123 \mathrm{kN} / \mathrm{m}$, and $142 \mathrm{kN} / \mathrm{m}$. The strain at maximum tensile strength is $11 \pm 3 \%$.
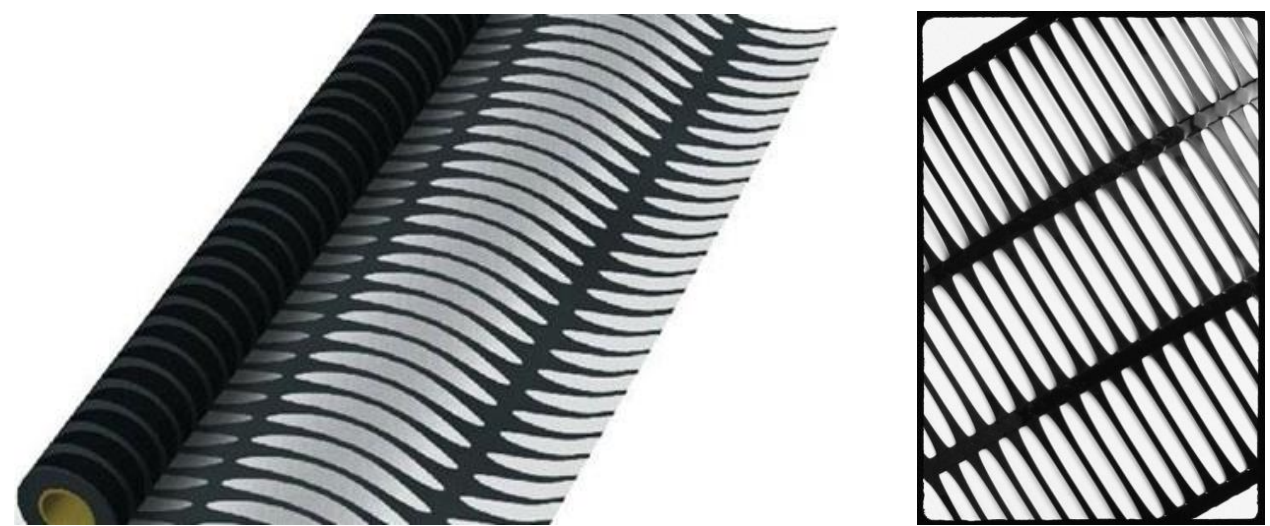

Figure 3 Uniaxial geogrids made of high-density polyethylene used for the RSRW (image source: http://www.tensar.co.uk/)

Vertical structures of reinforced soil always require a facing. To accelerate construction, it was necessary to eliminate the concrete blocks, because the concrete takes time to strengthen. Thus, for this wall we used the steel mesh panel system. The face of the slope was formed with swaddled steel nets with a side lengths of $2 \mathrm{~m}$ (Figure 4). These nets serve as a formwork for the fill and allows greening of the face. These steel meshes are connected to the geogrid reinforcement. They are wrapped from the inside with geotextile $\left(100 \mathrm{~g} / \mathrm{m}^{2}\right)$ or jute cloth to prevent erosion of surface material or fallout of fill material and to enable greening of the face, improving the structure's appearance. 

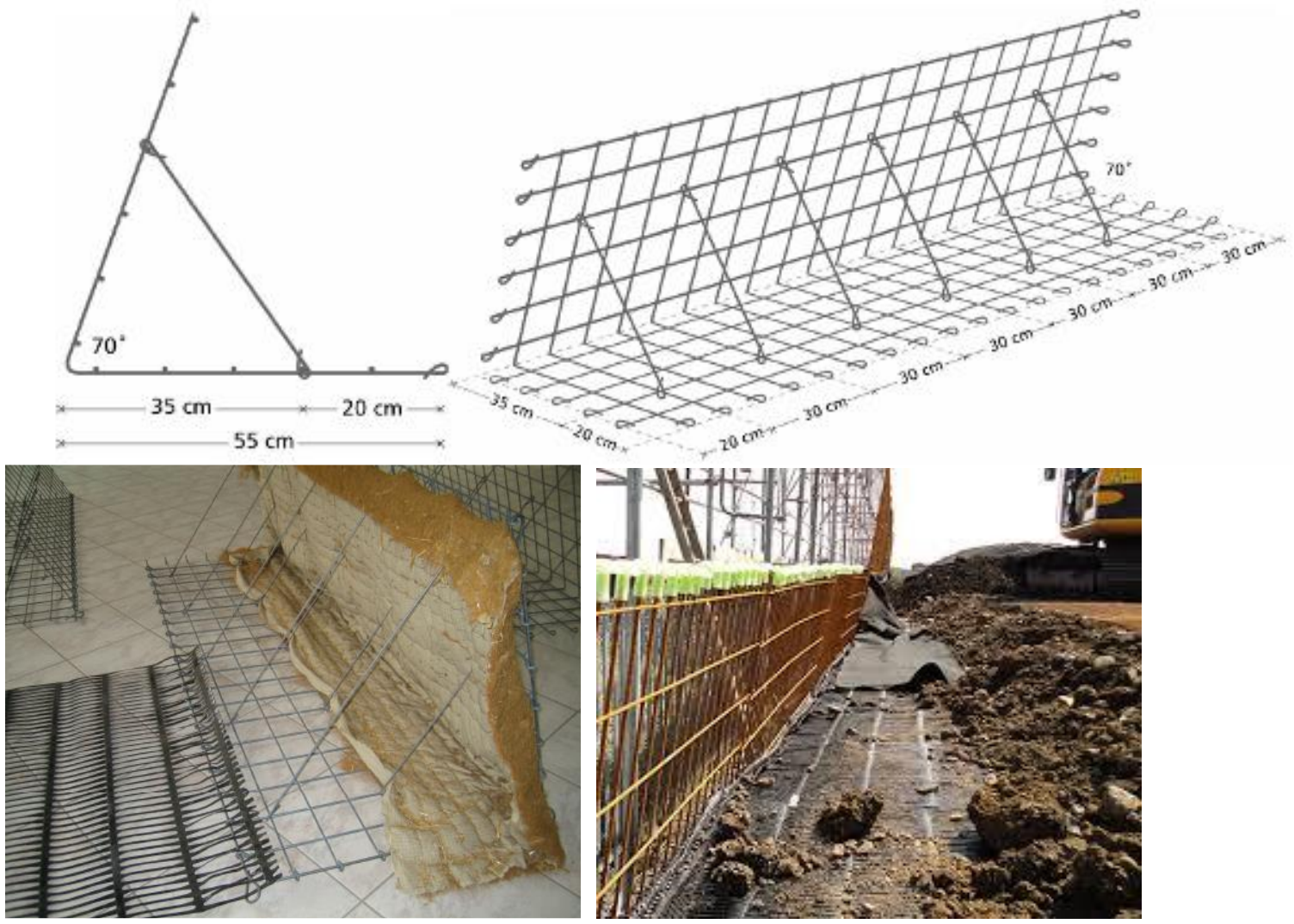

Figure 4 Diagram and pictures of the swaddled steel mesh (image source: http://www.tensar.co.uk/)

The swaddled steel meshes are connected to the geogrids with steel bodkins (Figure 5).

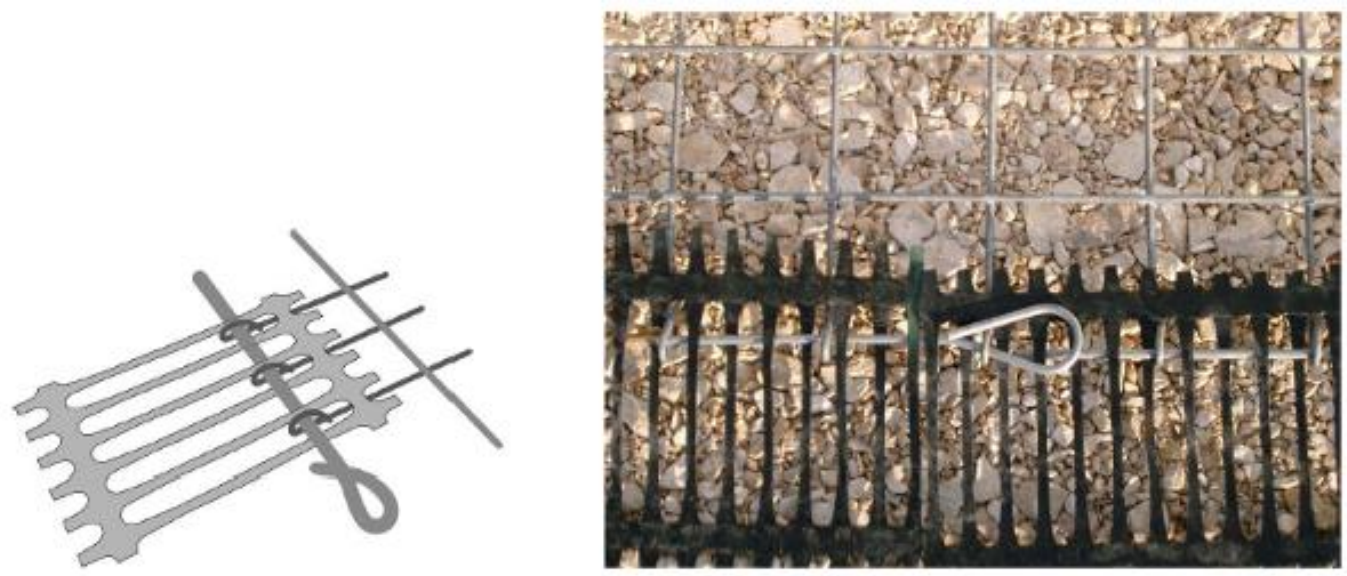

Figure 5 Connection of swaddled steel meshes and geogrids with a bodkin (image source: http://www.tensar.co.uk/)

\section{NUMERICAL ANALYSIS}

A RSRW can be designed with various software packages, but we used TensarSoil v.2.07. The detailed procedure can be found in the literature [3]. First, we enter the geometric characteristics of the wall, and then select the type of wall face. We selected the steel mesh panel (SMP) system, a steel reinforcement formwork, to decrease the length: that is, to avoid possible longer slopes. 
It was also limited by the height of the highest section of the wall, which is situated in an area with limited free space because of the nearby regulation lines and surface drainage channel. Namely, at that location the wall is about $10 \mathrm{~m}$ high, and the horizontal distance between the top of the fill and the regulation/building line is about $6 \mathrm{~m}$; about $1.5 \mathrm{~m}$ should be left for the fence and surface drainage channel, which leaves only about $4 \mathrm{~m}$ for the wall toe.

The wall was built on sandy gravel with silty particles defined by a bulk density of $\gamma=20.0 \mathrm{kN} / \mathrm{m}^{3}$, an angle of internal friction of $\varphi=30^{\circ}$, and a cohesion of $c=5.0 \mathrm{kPa}$. The fill material was defined by $\gamma=20.0 \mathrm{kN} / \mathrm{m}^{3}, \varphi=23^{\circ}$, and $c=4.0 \mathrm{kPa}$. The software we used allows for entry of various positions and intensity of external load, and the sections are designed to allow a traffic load of $16 \mathrm{kN} / \mathrm{m}^{2}$. The factors of mutual effects during pull-out and slide are set before beginning the analysis of the wall. Beside static loading, the walls are designed to also accept seismic loading with intensities of $a_{v}=0.1 \mathrm{~g}$ and $a_{h}=0.05 \mathrm{~g}$.

During the calculation, the software controls the inner stability of the wall, the bearing capacity of the foundation through the safety factor of $F s=5.02$, the position (i.e., eccentricity) of the resultant force $e=-1.57 \mathrm{~m}$, and the risk of structure sliding ( $F s=2.39$ ), as well as the force development along the geogrid. If any one factor is not satisfied, the software refuses to confirm the wall's stability, demanding adjustment of parameters or geogrids.

The software outputs a significant amount of data, including the type of automatically selected geogrid appropriate for the forces that occur at a particular depth and the spacing between the geogrids used. The data is then graphically represented, giving insight into the geometric characteristics of the wall, the lengths of the geogrids, along with their starting and ending coordinates, where they are fixed between the concrete elements from the wall face, as well as the results of the calculations. The face elements used in the calculation could be replaced by a wire face during construction because they do not affect the global stability of the wall and they are only used to fix the geogrid. The results are shown in Figure 6.

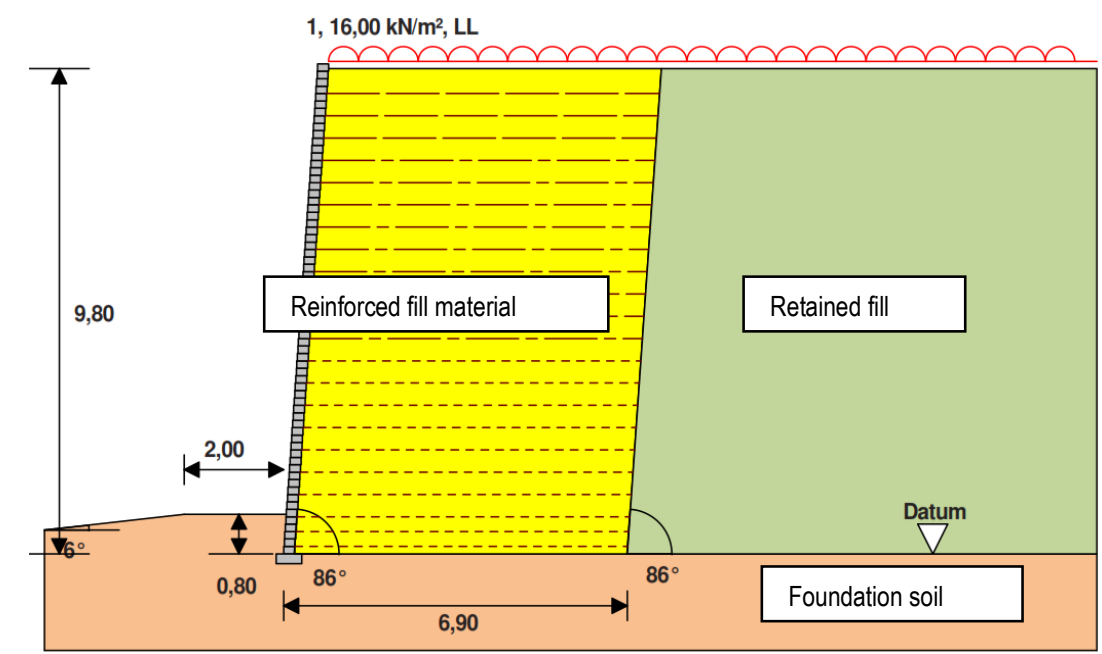

Figure 6 Cross-section of a wall made with concrete blocks and the details of the facing foundation

The wall is constructed with four types of uniaxial geogrids (from bottom to top): one RE570 geogrid, two RE570 geogrids with a vertical spacing of $0.3 \mathrm{~m}$, seven RE570 geogrids with a vertical spacing of $0.45 \mathrm{~m}$, two RE540 geogrids with a vertical spacing of $0.45 \mathrm{~m}$, four RE520 geogrids with a vertical spacing of $0.45 \mathrm{~m}$, and five RE510 geogrids with a vertical spacing of $0.45 \mathrm{~m}$.

Unfortunately, the design software we used cannot analyze the overall stability, so to test this we used Slide software. This software is based on the method of limit equilibrium, and it allows us to enter the geometric characteristics of the section and the mechanical parameters and strengths of all materials in the section: the soils, concrete, geogrid, external impacts, and so on. In this model, geogrids are drawn as a "geotextile support system" defined by the same tensile strengths as those used in the previous analysis. The centers of the circularcylindrical sliding surfaces are positioned in a rectangular surface that should be set, and the software models every sliding surface in several ways, including Bishop's method, the general method for limit equilibrium (GLE), and Spencer's method [4]. The software then determines the smallest of all the calculated safety factors and the surface for which it applies. The results in Figure 7 show that the wall is stable. 


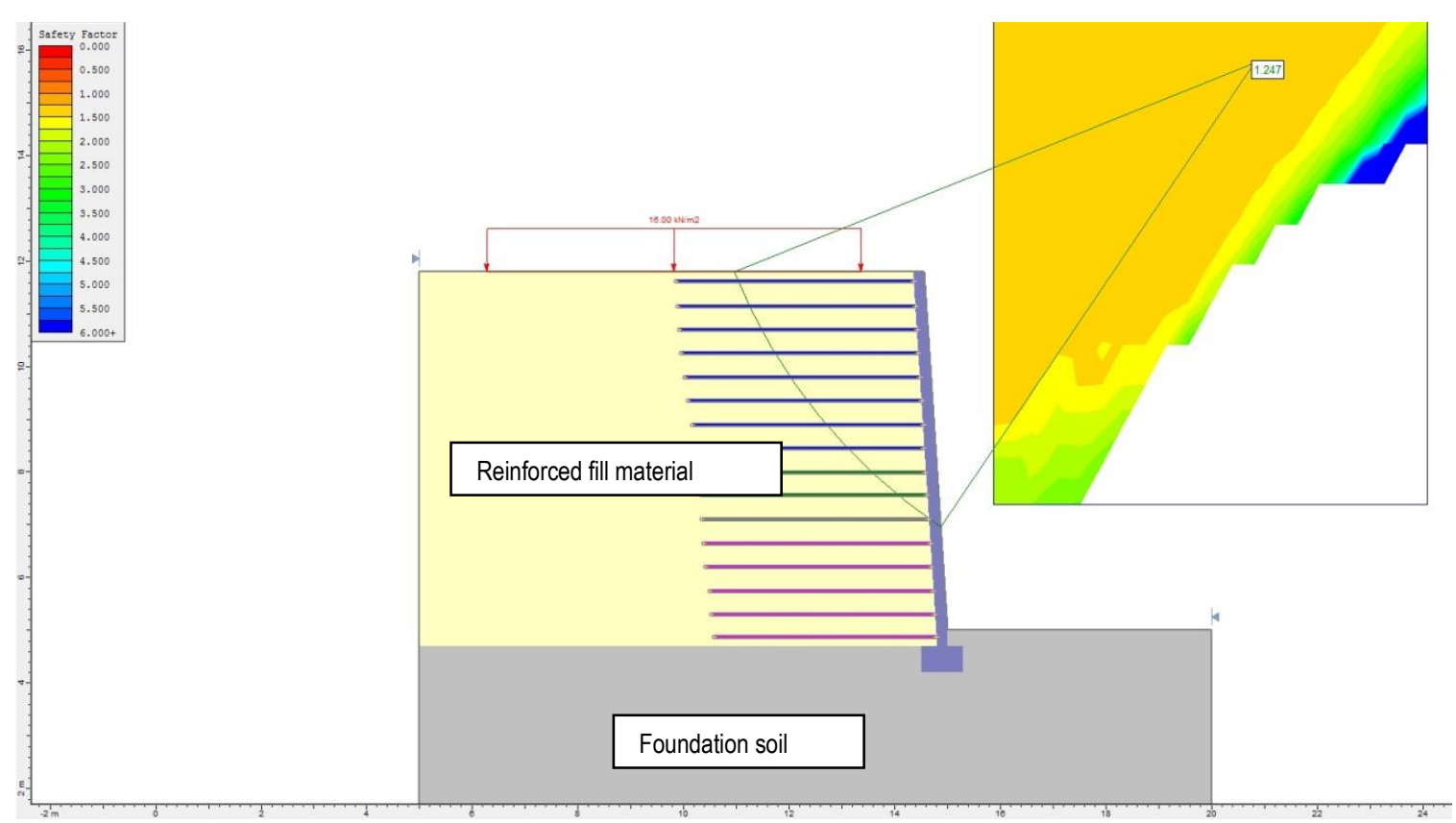

Figure 7 View of the critical sliding surface of the RSRW and its safety factor

The safety factors obtained for a permanent static condition are 1.5 for static conditions and 1.25 for seismic conditions.

Using PLAXIS 2D software, we checked the RSRW with a stress-deformation analysis by using the finite element method with plane and geogrid elements. This program is designed to analyze complex geotechnical structures that interact with buildings [5]. The modeling includes drawing the model geometry and selecting the material model to simulate the soil behavior. A plain strain model is analyzed, so the obtained results refer to 1.0 $\mathrm{m}$ from the structure. Finite elements with 16 nodes were used. When the model is developed, standard horizontal fixities are adopted at the end of the geometrical model input, as shown in Figure 8.

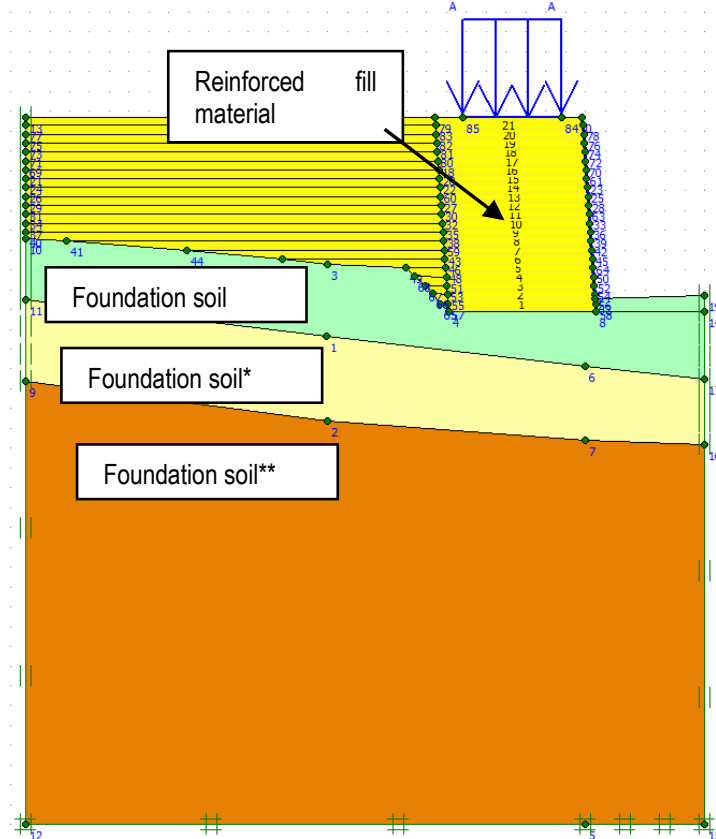

(a)

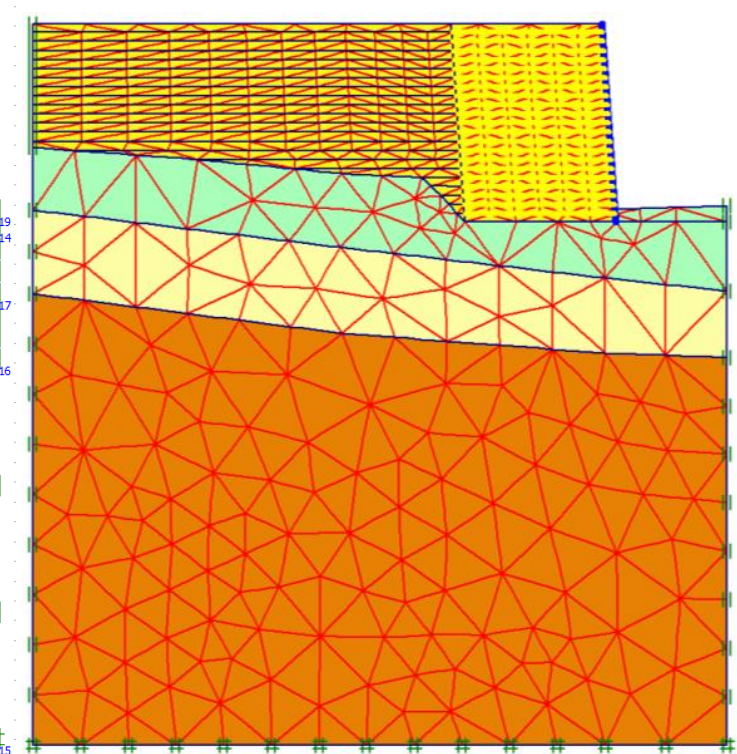

(b)

Figure 8 (a) Geometry of the analyzed model and (b) the finite element mesh

The soils are defined by Mohr-Coulomb material behavior. The material is described with five basic input parameters: natural unit density $(\gamma)$, modulus of compressibility $\left(E_{o e d}\right)$, Poisson's ratio $(U)$, angle of internal friction 
$(\varphi)$ and cohesion $(c)$. In this model, the geogrids are described with axial rigidity, which is the product of the elasticity modulus and cross-sectional area. The interaction between the fill material and geogrids is defined through interface elements with a chosen friction coefficient $R_{\text {inter }}$ of 0.7 . Table 1 shows the chosen soil parameters.

Table 1 Input parameters in Plaxis 2D for analyzing the retaining wall

\begin{tabular}{|c|c|c|c|c|c|c|}
\hline Parameter & Symbol & Units & Fill material & Foundation soil & Foundation soil $^{*}$ & Foundation soil $^{* *}$ \\
\hline Material model & & & $M C$ & $\mathrm{MC}$ & $M C$ & $\mathrm{MC}$ \\
\hline Conditions & & & Drained & Drained & Drained & Drained \\
\hline $\begin{array}{l}\text { Natural unit } \\
\text { weight }\end{array}$ & Yunsat & {$\left[\mathrm{kN} / \mathrm{m}^{3}\right]$} & 20.0 & 20.0 & 19.0 & 21.0 \\
\hline $\begin{array}{l}\text { Modulus of } \\
\text { compressibility }\end{array}$ & Eoed & {$[\mathrm{kPa}]$} & 30000 & 35000 & 30000 & 50000 \\
\hline Poisson's ratio & $v$ & {$[-]$} & 0.28 & 0.3 & 0.3 & 0.3 \\
\hline Cohesion & $c$ & {$[\mathrm{kPa}]$} & 4 & 5 & 10 & 20 \\
\hline $\begin{array}{l}\text { Angle of internal } \\
\text { friction }\end{array}$ & $\varphi$ & {$\left[^{\circ}\right]$} & 23 & 30 & 26 & 30 \\
\hline $\begin{array}{l}\text { Angle of } \\
\text { dilatation }\end{array}$ & $\psi$ & {$\left[^{\circ}\right]$} & 0 & 0 & 0 & 0 \\
\hline
\end{tabular}

Once the geometry and material characteristics are entered, the finite element mesh and the initial stresses in the soil are generated. Figure 9 shows the deformation results obtained from this analysis.

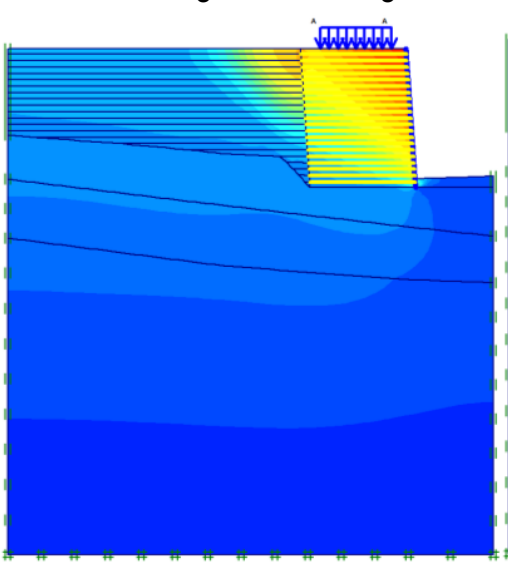

Total displacements (Utot)
Extreme Utot $486,76^{*} 10^{-3} \mathrm{~m}$

(a)

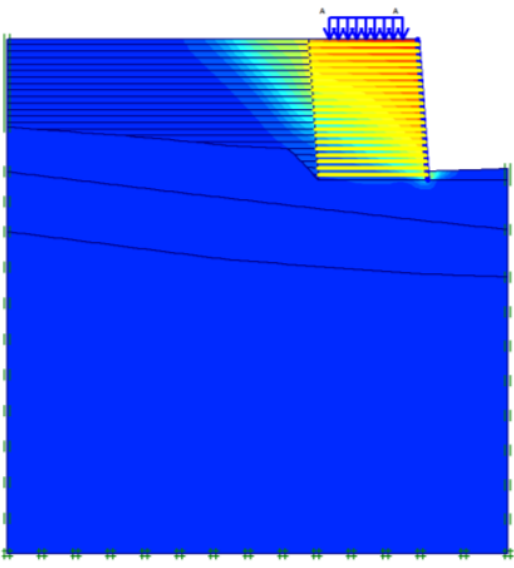

Horizontal displacements (Ux)
Extreme Ux $330,52^{2} 10^{-3} \mathrm{~m}$

(b)

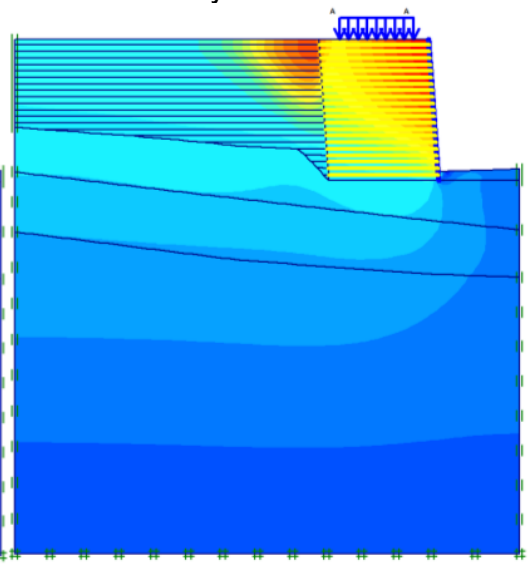

Vertical displacements (Uy)
Extreme Uy $-357,65^{*} 10^{-3} \mathrm{~m}$

(c)

Figure 9 Shading plot of the (a) total, (b) horizontal, and (c) vertical deformation after construction

The maximal total displacement is $48.67 \mathrm{~cm}$, the maximum horizontal displacement is $33.05 \mathrm{~cm}$, and the maximum vertical displacement is $35.76 \mathrm{~cm}$, all on the top surface of the RSRW. These deformations accumulate throughout the construction phases and will probably be noticed during construction. After the full height is constructed, it could become necessary to add another layer of unreinforced material with good bearing capacity. Deformation is not expected to occur after constructing the wall and the internal road behind it. The maximal total displacement of the base material, in contact with the retaining wall, is $15.0 \mathrm{~cm}$. The global safety factor obtained from the " $\varphi-c$ reduction" analysis is 1.42 .

Figure 10 plots the shear stresses in the soil body and RSRW. The maximal shear stress is $97.07 \mathrm{kPa}$, occurring in the toe of the wall. The total resisting capacity at the toe could not be confirmed by FOS calculation. 


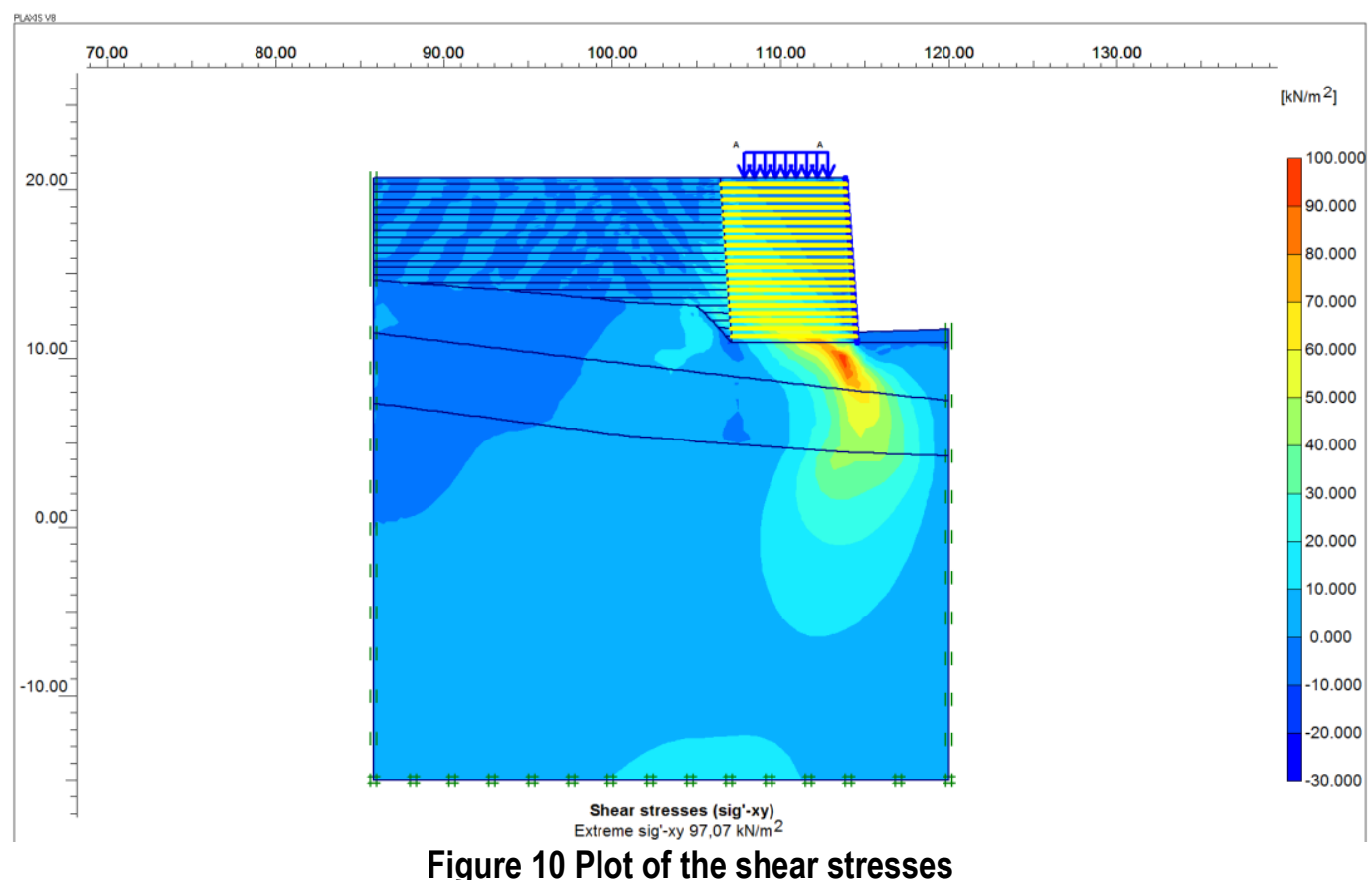

\section{CONSTRUCTION ASPECTS}

The wall system we used consists of steel mesh panels, connectors, geogrids, and fill, along with a drainage system, and its stability is provided by friction and fixing of fill grains with the geogrid and the connection of the geogrid to the steel mesh panels by bodkins.

First, the ground was excavated to the designated levels, then cleaned of any stones, roots, and other inhomogeneities. To provide horizontality and stiffness, it was necessary to compact the ground layer to produce a subgrade deformation modulus of at least $45 \mathrm{MPa}$.

At the back of the wall, on its contact with the backfill, a drainage geocomposite was positioned along with drainage perforated pipe $(d=200 \mathrm{~mm})$, wrapping it over the whole diameter.

The steel mesh elements were pre-bent to the required angle of the embankment.

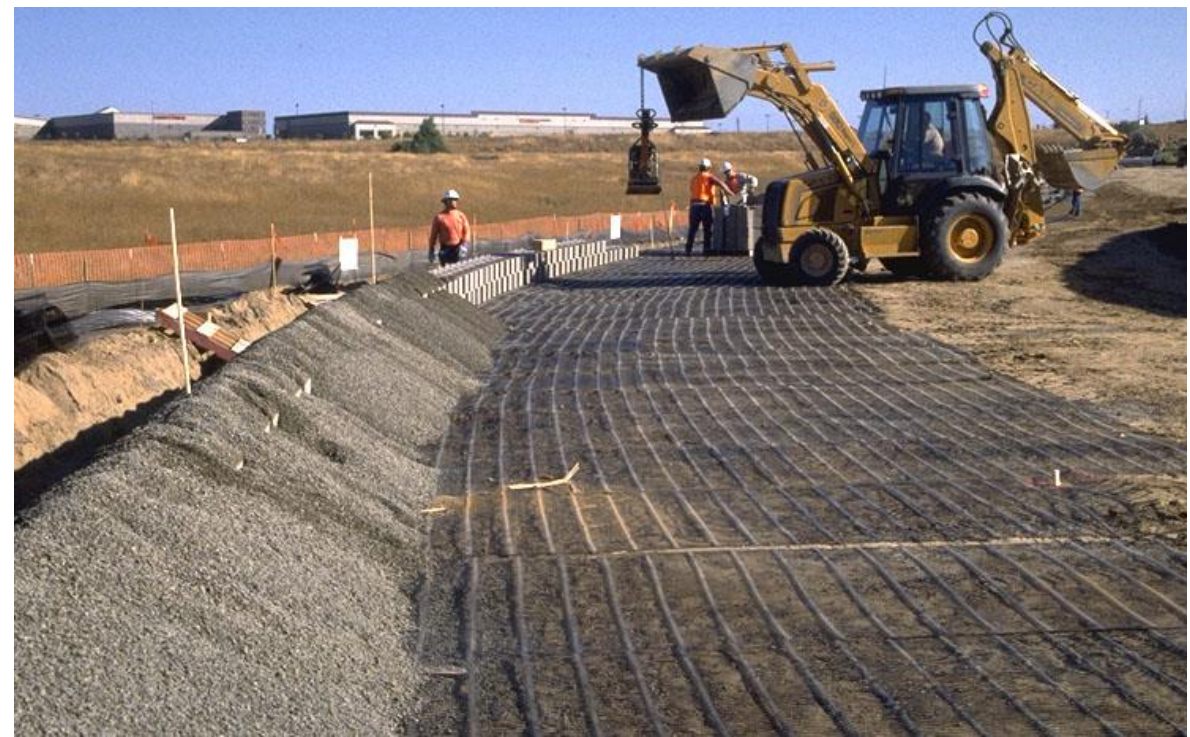

Figure 11 Placing the fill material between geogrids (image source:

http://research.engineering.ucdavis.edu/gpa/wp-content/uploads/sites/43/2015/02/Rein.-Soil-Wall-P3Labeled.jpg) 
The geogrid rolls were placed perpendicular to the slope, with the transverse bar end of the geogrid at the slope face (i.e., the steel mesh). The individual geogrid must be cut to the required length given by the calculation. The backfill material was installed in layers, each with a thickness of $30-50 \mathrm{~cm}$, in the pre-headprocess from the front to the free geogrid end, and the backfill was compacted (Figure 11). Figures 12 and 13 show pictures of the constructed RSRW and working platform.
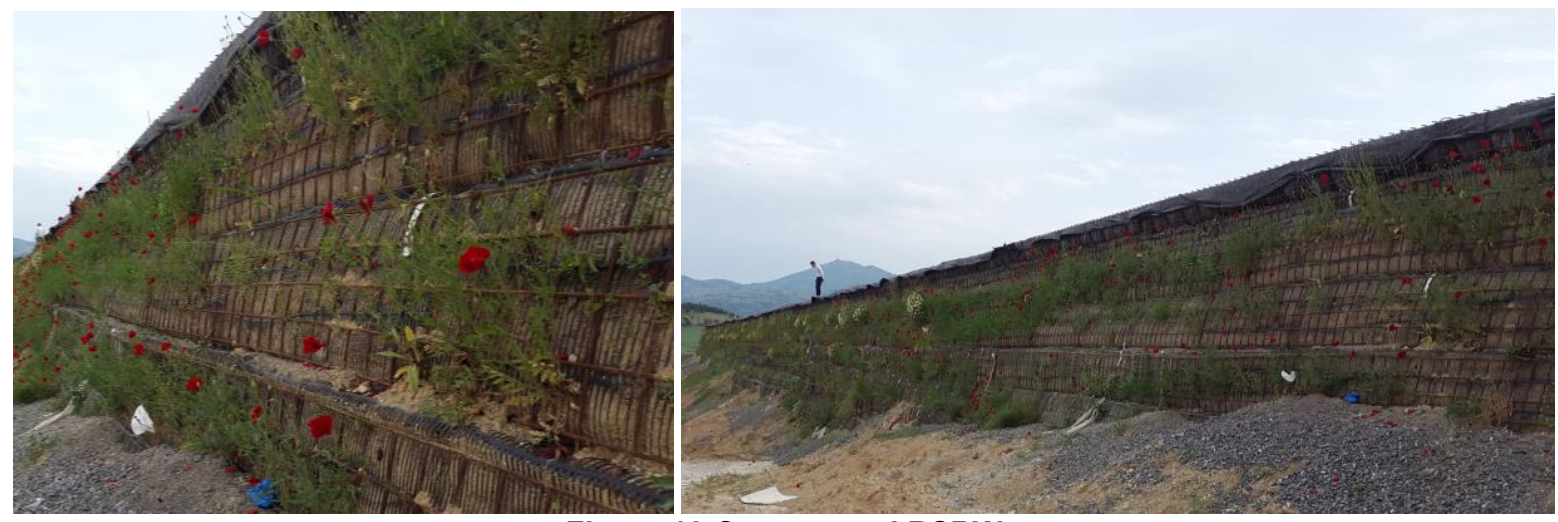

Figure 12 Constructed RSRW

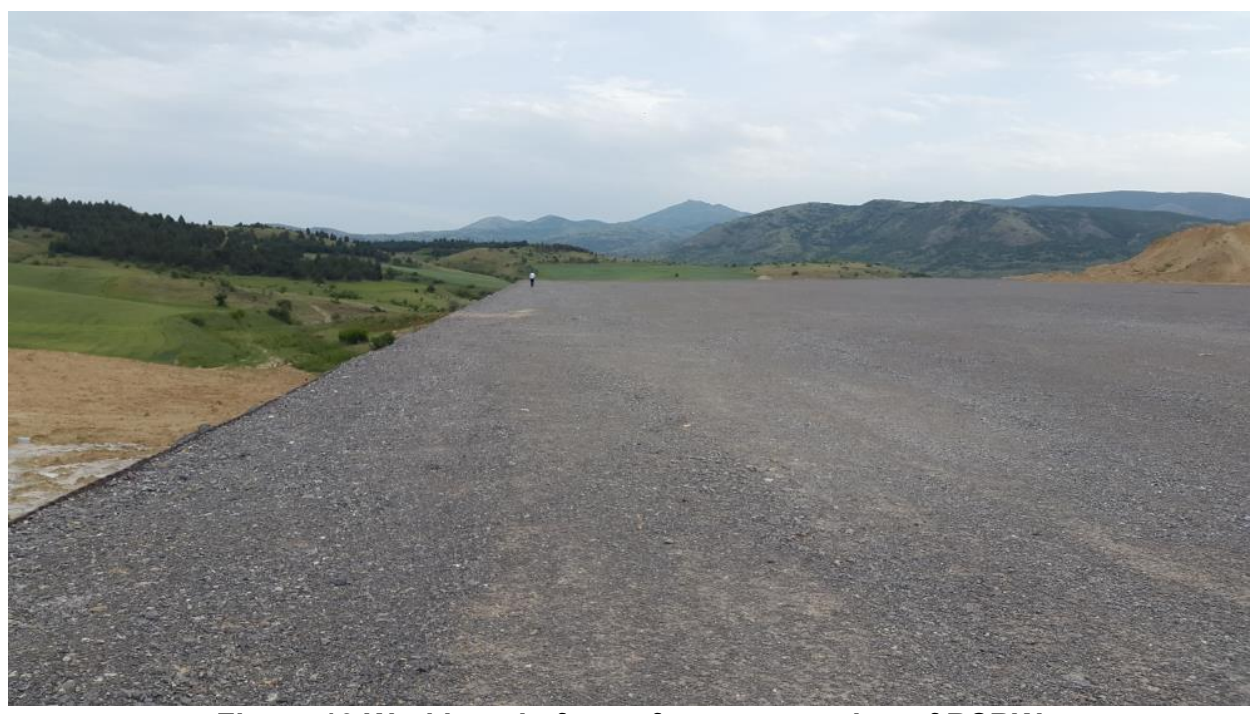

Figure 13 Working platform after construction of RSRW

\section{CONCLUSION}

We modeled and constructed a reinforced soil retaining wall, simulating the behavior of various components in these structures by using various numerical analyses and material models. A simplified calculation showed that the reinforced soil provides a number of advantages: the reinforced retaining structure can handle uneven settlements and adapt to new conditions. The main materials of this reinforced soil structure are the fill material and the reinforcement material: geogrids, facing materials, foundations, and so on. To validate the proposed geometry and check the stability from the TensarWall software, we used Slide to analyze the total static and seismic stability. Also, numerical analysis using the finite element method showed that relatively large settling accumulated throughout construction, which will probably be realized during construction. With this in mind, the materials used in this solution are environmentally friendly.

From these analyses, we conclude that the designed RSRW meets the requirements in both static and seismic conditions. In further analysis, it will be useful to compare the deformation obtained from the numerical calculation and the deformation measured on site after construction. 


\section{References}

[1] Gjorgjevski, S.; Papic, J.; Susinov, B. 2014: Design of reinforced soil retaining wall in the industrial zone of Veles, Faculty of Civil Engineering, Skopje.

[2] Rajagopal, K. 2015: Reinforced soil walls, IIT Madras, Chennai, p. 18, Accessed 15 October 2015, Available online: http://nptel.ac.in/courses/105106052/downloads/Lecture-9.pdf.

[3] TensarSoil v2.07, Accessed 09 June 2015, Available online: http://www.tensarcorp.com/Systems-andProducts/Tensar-geogrids/Tensar-Uniaxial-UX-geogrids.

[4] Slide slope stability verification manual, Accessed 09 June 2015, Available online: https://www.rocscience.com/help/slide/webhelp/pdf_files/verification/Slide_SlopeStabilityVerification_Part1.p df.

[5] Plaxis v8 manuals, Accessed 09 June 2015, Available online: http://www.plaxis.nl/plaxis2d/manuals/. 